\title{
Geotectonic Evolution and Metallogenesis in the Nujiang-Lancang-Jinsha Rivers Area, China
}

\author{
Zou Guangfu ${ }^{1}$, Zou Xin ${ }^{2,5}$, Mao Ying ${ }^{3}$, Mao Qiong ${ }^{4}$ and Xia Tong ${ }^{4}$ \\ 1. Chengdu Institute of Geology and Mineral Resources, China Geological Survey, Chengdu 610082, China \\ 2. Department of Psychology, Peking University, Beijing 100871, China \\ 3. Chengdu Comprehensive Rock and Mineral Testing Center, Sichuan Bureau of Geology and Mineral Resources, Chengdu 610081, \\ China \\ 4. Research Institute of Petroleum Exploration and Development, North China Oil Field Company, PetroChin, Renqiu 062552 , \\ China \\ 5. China Ocean Press, Beijing 100081, China
}

\begin{abstract}
The studied area lies in the eastern sector of the Tethys. Since the Early Paleozoic, the Nujiang-Lancang-Jinsha Rivers (southwest Sanjiang) area has experienced the geological evolutionary phase of the Paleo-Tethys, Meso-Tethys and Neo-Tethys. The multiple tectonic-magmatic activities have been occurred in the region, which have provided very favorable conditions. According to the regional geological characteristics, Geotectonic position is the area which can be divided into the following tectonic units: Kekexili-Yajiang passive continental margin, Garze-Litang plate junction, Dege-Zhongdian plate, Jinshajiang-Ailaoshan plate junction, Changdu-Simao plate, Lanchangjiang plate junction, Zuogong-Baoshan plate, Nujiang plate junction, Bomi-Tengchong plate and nine mineralization zones (Kekexili-Yajiang mineralization zone, Garze-Litang mineralization zone, Dege-Zhongdian mineralization zone, Jinshajiang-Ailaoshan mineralization zone, Changdu-Simao mineralization zone, Lanchangjiang mineralization zone, Zuogong-Baoshan mineralization zone, Nujiang mineralization zone and Bomi-Tengchong mineralization zone). The authors discussed that the geotectonic evolution specializes are relative to the main mineralization in this region. These studies show the geotectonic evolution and mineralization in the Nujiang-Lancang-Jinsha Rivers area have gone through eight stages for the Cambrian. Because the tectonic-magmatic mineralization activities have occurred the rich minerals resources and ore deposit types have been forming in this region. Ore deposits may be divided into seven types: massive sulfide type, stratabound type, turbidite type, postmag-matic hydrothermal type, skarn type, porphyry type and ductile shear zone type gold deposit. Deep geological effect of southwest Sanjiang area for deposit and its mineralization and ore prospecting and metallogenic prediction research work, is expected to find new orebody and ore deposit. The study of geotonics and metallogenesis in the Nujiang-Lancang-Jinsha Rivers area has a new idea and important foundation for prospecting for the ore deposits in Sanjiang (Nujiang-Lancang-Jinsha Rivers area) region.
\end{abstract}

Key words: Geotectonic evolution, mineralization, ore deposits, the Nujiang-Lancang-Jinsha rivers area.

\section{Introduction}

The Nujiang-Lancang-Jinsha Rivers (southwest Sanjiang) area lies in the eastern sector of the Tethys. Since the Early Paleozoic, the region had experienced oceanic crust subduction, continental arc collision and intracontinental convergence tectonic events. The tectonic magmatic activity is frequent and intense. Its

Corresponding author: Zou Guangfu, professor, research field: geology of Qinghai Xizang Plateau. E-mail: zguangfu@163.com. metallogenic condition is superior. China has rich mineral resources and is one of the important nonferrous metal and precious metal ore deposit concentration areas. With the formation of large and super large metal deposits condition, prospecting potential is tremendous (Bureau of Geology and Resources of Sichuan, 1991; Bureau of Geology and Mineral Resources of Xizang Autonomous Region, 1993; Bureau of Geology and Resources of Yunnan, 1990; Chen et al., 1987; Hou and Mo, 1991; Hou et al., 
2006; Huang and Chen, 1987; Hu et al., 1995; Li et al., 2011; Li and Zeng, 2012; Li 2002; Liu et al., 1990, 1993; Pan, 1994; Wang et al. 2000; Xiao et al., 1990; Xu et al., 1992; Yin, 2000; Zhong, 1998; Zou, 1996) [1-20]. In this paper, according to the author for Sanjiang region tectonic evolution and metallogeny and the special research of typical deposits, southwest of the Sanjiang region tectonic evolution and the main metal mineral deposits of the relationship among mineralizations are discussed. The ore-forming geological background, ore-depositing geological characteristics of metallogenic regularities and prospecting direction have been discussed in southwest Sanjiang area. In order to promote prospecting exploration work in this area, we have achieved a major breakthrough in the prospecting work which provides a new train of thought.

\section{Geological Settings}

The southwest

Sanjiang

area

(Nujiang-Lancang-Jinsha Rivers) located in the eastern Qinghai-Tibet plateau, belongs to a part of the Alps and the Himalayan orogenic belt. Geotectonic position is the area which can be divided into the following tectonic units (Fig. 1): Kekexili-Yajiang passive continental margin, Garze-Litang plate junction, Dege-Zhongdian plate, Jinshajiang-Ailaoshan plate junction, Changdu-Simao plate, Lanchangjiang plate junction, Zuogong-Baoshan plate, Nujiang plate junction, Bomi-Teng chong plate and nine mineralization zones (Kekexili-Yajiang mineralization zone, Garze-Litang mineralization zone, Dege-Zhongdian mineralization zone, Jinshajiang-Ailaoshan mineralization zone, Changdu-Simao mineralization zone, Lanchangjiang mineralization zone, Zuogong-Baoshan mineralization zone, Nujiang mineralization zone, Bomi-Tengchong mineralization zone) (BGMRS, 1991; BGMRX, 1993; BGMRY, 1990; Chen et al., 1987; Hou and Mo, 1991; Huang and Chen, 1987; Zou, 1996) [1-5, 7, 20]. The area is a key areas and important window in the study of the Qinghai-Tibet plateau geological structure and Tethys and Himalaya tectonic evolution and metallogeny. The multiple tectonic-magmatic activities have occurred and created favourable conditions for metallic ore deposits formation and rich mineral resources. China is one of the most important ore concentration areas.

From the Precambrian to Early Paleozoic Era, the primitive Laurasia is connected with the primitive Gondwanaland and forming the first Pangaea after the Pan-African movement. As it entered the evolutionary phase of the Palea-Tethys Ocean, it had developed a relatively stable clastic rocks sedimentary formation, carbonatite rocks and a small amount of volcanic rock with the scope of the ancient Yangtze plate. In the Late Paleozoic Era, the first Pangaea broke up and brought about fracturing. In the Carboniferous Period, the Lantsang River and the Jinsha River River were unfolded successively and entered an expansion period, beginning the evolutionary phase of the Paleo-Tethys Ocean. In the Late Permian Epoch, as the Eurasian Plate collided and integrated with Gondwanaland, it put an end to the development phase of the Paleo-Tethys Ocean and began the geological evolution of Meso-Tethys. At the end of the Late Permian Epoch, as the Jinsha River oceanic crust subducted westward, extensive ground fracturing happened in the southwest edge of the Eurasian Plate and began to form primary rift zones, such as the Garze-Litang and Xianshui River and deposited a geosynclinal flysch formation as thick as more than tens of thousands meters. At the initial stage of this sedimentary basin, it amounted to a back-arc basin with several fracturing centers. However, among those rift zones, only Garze-Litang River had further developed into a sea-floor spreading center to form Garze-Litang Ocean Basin. Since the Late Triassic Epoch, it had subducted westward with the Garze-Litang oceanic crust to form the Yidun island arch. At the end of Late Triassic Epoch, as the Yidun island arch collided and pieced together with the Yangtze 


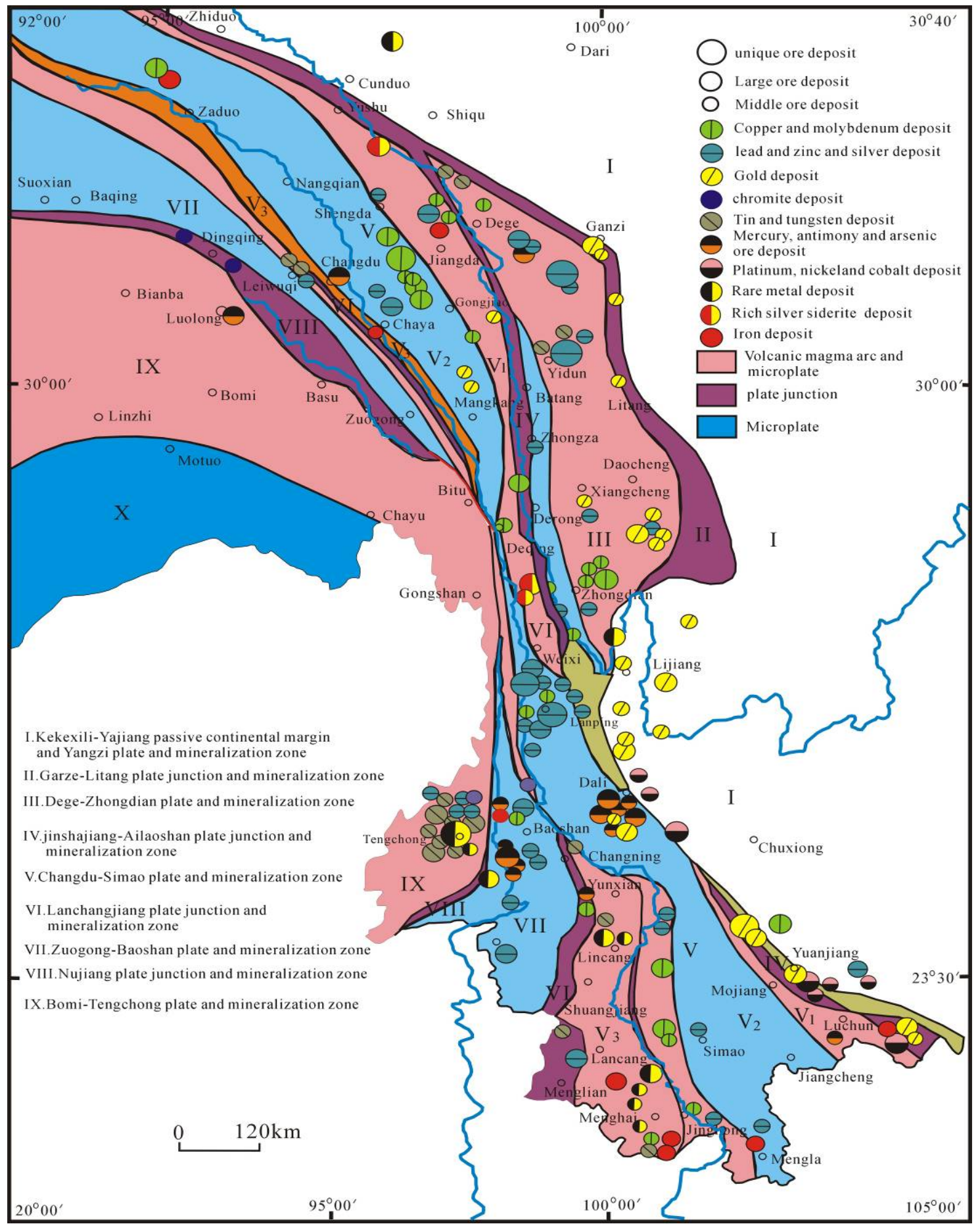

Fig. 1 Map showing tectonic units and mineral distribution in the southern part of the the Nujiang-Lancang-Jinsha Rivers (after Liu et al., 1993; Luo et al., 1999; Pang et al., 2003; Li, 2012)[13, 21, 22].

landmass, the Garze-Litang Ocean was closed and the whole western Sichuan area was entirely lifted to form a land as seawater receded towards east. Then, it began to enter the later evolutionary phase of Meso-Tethys. In the Early and Middle Jurassic Period, sea-floor spreading happened along Bangong Lake-Dingqing-Nujiang River and has formed the Bangong Lake-Nujiang Ocean Basin. In the Middle and Late Jurassic Period, the Nujiang Ocean was closed due to the oceanic crust subduction. The ocean 
of Yarlung Zangbo River started to be formed in the Early Cretaceous Epoch. From the Late Cretaceous Epoch to the Eocene Epoch, the Yarlung Zangbo River Ocean was closed and the Indian Plate collided and pieced together with the Lhasa Plate, which put an end to the geological evolution of Meso-Tethys and started the geological evolution of Neo-Tethys at the west side of south Yarlung Zangbo River. Starting from the Tertiary Period, the whole three-river area entered an intracontinental compressive orogenic period.

\section{Classification and Characteristics of Metallogenic Belt}

The three-river region in the southwest is very abundant in mineral products, especially famous for gold, copper ore, lead zinc ore and iron ore deposit. There are quite many genetic types for the deposits and most of the deposit (mineral occurrence) and abnormality are under the control of north-east direction trending structure and north-south direction trending structure. According to the geotectonic setting of ore forming and geological conditions for ore forming and the characteristics of the distribution of deposits, it can be preliminarily classified into nine metallogenic belts (Fig. 1).

\subsection{Hoh Xili-Yajiang Metallogenic Belt}

Hoh Xili-Yajiang Metallogenic Belt starts from the north of Tuotuo River in the west and stretches to Muli County, Sichuan in the southeast with a width of 200-700 km and a length of more than $900 \mathrm{~km}$. In the metallogenic belt, there are several tens of lead and zinc deposits and large medium-sized Manaoke gold deposits, Dongbeizhai, Qiaoqiaoshang, Zheposha, Qiuluo, Puloba and Shilozhao, etc., which have revealed a good metallogenic prospecting. Deposits of this kind are mainly located in the Bayanhar turbidity sedimentary basin and the mineralization all appeared in the Triassic abyssal and bathyal turbidity sedimentary flysch formation.

\subsection{Garze-Litang Metallogenic Belt}

The metallogenic belt is located in Garze-Litang suture zone (Fig. 2). It starts from the Sancha River in Derge, then stretches westward to Yushu, Qinghai and extends southward passing Yulong, Garze, Litang to Muli. It is in the shape of arc-shaped strip in reverse " $\mathrm{S}$ " protruding northeast with its south part broader than the north part. It has an extension of about $700 \mathrm{~km}$ and a width of 10-100 km (Fig. 2). Along the fault zone, there are various boundary geologic bodies, such as

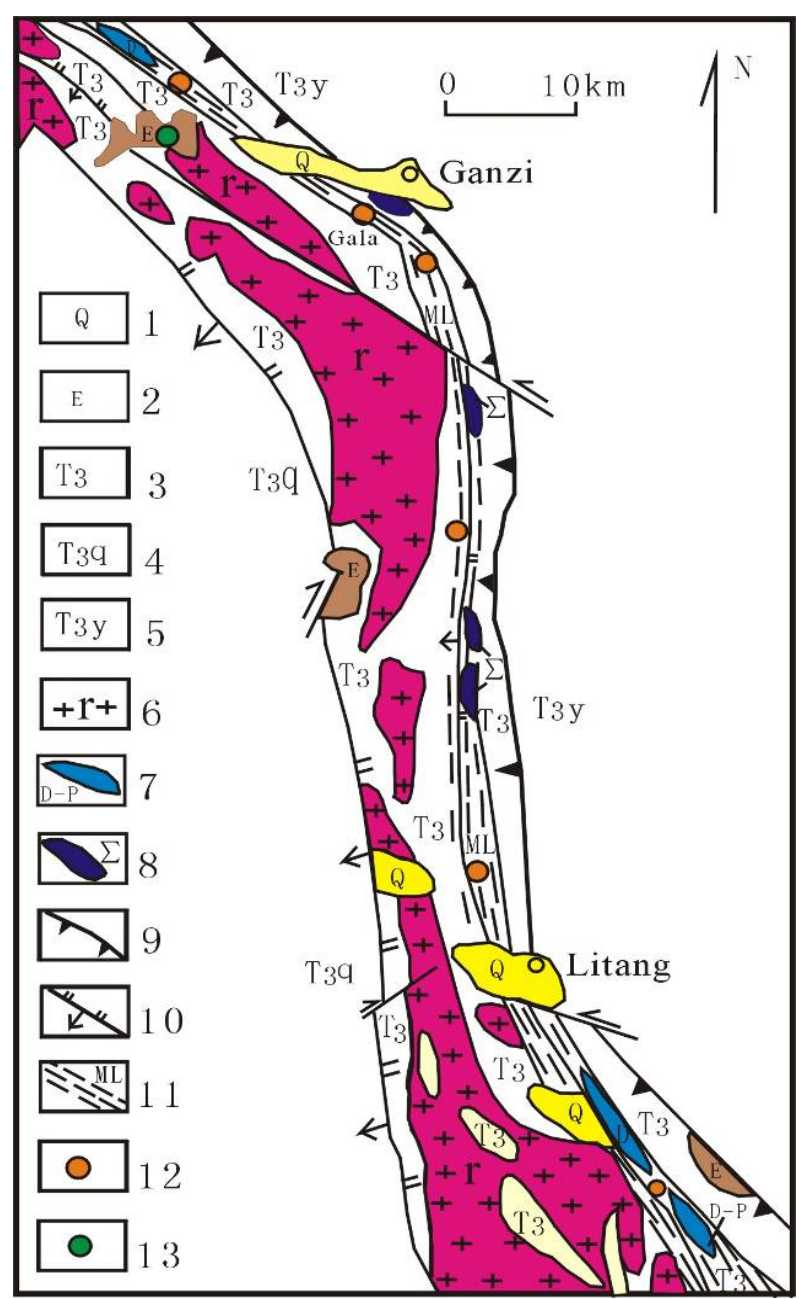

Fig. 2 Schematic map showing the geological structure of the Garze-Litang fracture zone.

1. Quaternary; 2. Paleocene; 3. Ophiolite melange zone; 4. The Triassic Qugashi formation; 5. The Triassic Yajiang formation; 6. Granite; 7. Paleozoic geological block; 8. Ultrabasic rock block and ophiolite combination; 9. Plate subduction zone; 10. Reverse fault; 11. Ductile shear zone; 12. Gold deposit; 13. Copper deposit. 
island arc volcanic rocks, sedimentary rocks, ophiolite tectonic massif and passive epicontinental flysch, with the Yanshanian acidic magmatic intrusion. Multi-period tectonic magmatic activities had provided very favorable minerogenetic conditions for the activation, migration and enrichment of mineralization of gold scattered in this area. Meanwhile, this fault zone is also a shear zone where gold deposits have a concentrated distribution. At present, orefield such as Gala gold deposit has been discovered successively in the Garze-Litang Plate juncture, showing a huge prospect for gold formation in this area. The gold mineralization of this kind mainly took place in the mylonite in the ductile shear zone and the occurrence of gold ore is mainly in the central part of the mylonite zone. The ore rocks are mainly mylonite and mylonite-type ore. The types of ore rocks are mainly micro-disseminated alteration phyllonite type and micro-disseminated sulfide stock work ore (Zou and Mao, 1996) [23]. Therefore, this area is an important metallogenic prospect district with large and medium-sized gold deposits in the "three-river" area.

\subsection{Derge-Chungtien Metallogenic Belt}

The metallogenic belt is located in the Derge-Chungtien microplate, between the Garze-Litang plate suture zone and the Jinshajiang plate suture zone, including three secondary metallpgenic belts: Yidun Island Arc Belt, Zhongzan Massif and Qiasi Dome Belt. In Late Triassic Epoch, Yidun Island Arc Belt had mainly developed Triassic series island arc instable calc alkalic volcanic rocks, clastic rocks, carbonate rocks sedimentary formation. At present, in the Yidun island arc collision zone, some volcanogenic massive sulfide polymetallic deposits formed related to Late Triassic Epoch island arc acidic volcanic activities have been discovered.

For example, super-huge polymetallic deposit in Xia village and several small deposits, mineral occurrences and mineralized spots in Changtai, Zengke volcanic sedimentary basin and many abnormalities all occurred in the Derge-Xiangcheng volcanic metalogenic belt in west Sichuan. The main characteristic of polymetallic deposits of this kind is that the ore body was generated in the volcanic and under the control of submarine volcanic eruption-sedimentary structure magmation and volcanic edifice. The deposits were mainly generated in the Yidun island arc and volcanic related to Late Triassic island arc acidic volcanic activities. The ore types are mainly massive polymetallic ore with sphalerite as the main ore mineral and quartz as gangue mineral. Hydrothermal alteration related to gold mineralization is featured with barium ice feldspathization. As the geochemical investigation on the isotopes of hydrogen and oxygen in rocks and ores indicates, this type of deposit belongs to marine volcanic eruption sedimentary deposit (Hou et al., 2006) [6].

The stripping fault zone and its rock fracture in Qiasi Dome Belt in the south Xiangcheng County in the south of the Yidun island arc belt fault zone are characterized with Erze gold deposit. Gold deposits in this type mainly distribute in Shuiluo River dome structure in the south of the Yidun island arc metallogenic belt. Shallow metasandstone in the Sinian-Triassic System emerged in the dome belt. Gold mineralization and gold ore were produced in the tectonic crushed zone of the volcaniclastic rock in the medium bed and massive marble thin bed in the Upper Permian series Gangdagai Fm. In the south of the Yidun island arc, Putang, Yunnan Province, there is a hypabyssal-superhypabyssal mineralized porphyry belt in the indo-china period and Pulang ultra-large porphyry copper ore deposit formed.

Yidun Comolong Sn-polymetallic deposits were produced in the Yidun island arc back-arc basin Triassic turbidite in the west of the Yidun island arc belt in the west Sichuan and Yanshanian and Himalayan granite intrusive contact zone (Liu et al., 1990, 1993; Lu et al., 1993; Wang et al., 2000; Zou, 1996) [12, 13, 15, 24, 25]. 
In the carbonate rocks in Zhongzan Massif, Najiao and Gangriluo Fm lead zinc ore is produced.

\subsection{Jinshajiang-Ailaoshan Mineralization Belt}

The metallogenic belt is located in the Jinshajiang-Ailaoshan plate junction, between Xiquhe fracture and Batang-Riyu fracture. It starts from the Denke, and then stretches southeast to Yushu, Batang, Benzilan, Diancangshan and Ailaoshan. It stretches in north-west direction trending and northwest-southeast direction as a belt, which has an extension of about $1,200 \mathrm{~km}$ and a width of $40-100 \mathrm{~km}$. Along the fault zone, there are various tectonic massifs such as ophiolite tectonic massif, flysch, island arc volcanic rocks, and sedimentary rocks, which is consisting of Devonian to Triassic basic-intermediate and acid volcanic rocks along the suture zone (fault zone). The multi-period tectonic magmation had provided very favorable minerogenetic conditions for the activation, migration and enrichment of mineralization of gold scattered in this area. This fault zone is also a place where shear zone type gold deposits have concentrated distribution. At present, the large and medium-sized gold deposits discovered mainly concentrated in the Ailao mountains and Batang area, such as Jinchang Fm gold deposit, Daping Fm gold deposit and Wangdalong Fm gold deposit (Hu et al., 1995; Liu et al., 1990, 1993; Lu et al., 1993; Wang et al., 2000; Zou, 1996) [8, 12, 13, 15, 20, 24].

\subsection{Changdu-Simao Mineralization Belt}

The metallogenic belt is located in the Changdu-Simao microplate, between the Lantsang River suture zone and the Jinsha River-Ailao mountains suture zone. It can be further classified into three metallogenic subzones according to the three secondary tectonic units included (Liu et al., 1993; Zou, 1996) [13, 20]. The Jiangda-Weixi-Luchun Indosinian volcanic arc metallogenic subzone is in the east with the Jinsha River suture zone in the east and the Deqin-Weixi-Qiaohou fault in the west as the boundary. It developed Permian-Late Triassic Hercynian Period-Indosinian intermediate and acid magma intrusive activities. At present, Yangla Skarn type copper deposit, Zongya Porphyry copper deposit, Luchun copper ore, lead ore and zinc ore have been discovered in the area.

Changdu-Lanping-Simao metallogenic subzone is located between the Jiangda-Weixi-Luchun volcanic arc in the east and the Zaduo-Jinghong island arc zone in the west. The stratum emerged is the Ordovician-Paleocene stratum. The Paleozoic stratum is a set of flysch sandy slate. The Early and Middle Triassic series are clastic rocks, acid volcanic mixed with carbonate rocks; the Late Triassic series-cretaceous is red molasse in littoral neritic facies and continental facies. And its red clastic rocks mixed with intermediate and acid volcanic in continental facies for Paleocene. In the Himalayan Yulong-Haitong porphyry zone in development, Yulong ultra-large type deposit containing gold, silver and copper were generated (Liu et al., 1993; Tang and Luo, 1995; Zou, 1996) [13, 26, 20]. The ore body which mainly relates to the mineralization of gold, silver and Mamupu copper is mainly early Himalayan monzonitic granite porphyry with an emplacement in group in form of stock. The mineralization of gold, silver and copper and its ore body are mainly produced within porphyry or the internal contact zone between porphyry and surrounding rocks. The main mineralization types of gold are disseminated, quartz vein mineralization and skarn type ore. In this metallogenic subzone in Yunnan Province, metal mineral occurrences such as Xinshan lead and zinc and silver deposit, Zacun gold deposit, Jinding ultra-large type lead and zinc deposit, Fulochang polymetallic deposit, Baiyangping polymetallic deposit and Chu Gezan, Qing Fu, Puear iron and sandstone type of copper deposits and gypsum salt deposits and a plurality of metal mine have been discovered (Hu et al., 1995; Li et al., 2011; Li and Zeng, 2012; Lu et al., 1993; Luo et al. , 1999; Wang et 
al., 2000) [8-10, 15, 24, 27].

Zaduo-Deqin-Jinghong metallogenic subzone is located between the Lanping-Simao Mesozoic volcanic arc and the Lancang river suture zone. Which emerged from it are mainly Carboniferous-Permian flysch clastic rocks with intermediate-basic island arc volcanic rocks and the Middle-Late Triassic series are mainly clastic rocks with acid volcanic and collision arc volcanic. In the island arc volcanic and collision arc volcanic, Dapingzhang, Sandashan, Minluo, Guanfang and Wenyu volcanic type copper deposit have been discovered (Hu et al., 1995; Li et al., 2011; Li, and Zeng, 2012; Wang et al., 2000) [8-10, 15].

\subsection{Lanchangjiang Mineralization Belt}

The metallogenic belt is located in Lanchangjiang suture zone. It started from the north of Dingqing and then passed Zuogong-Changning-Menglian in the south to the east. The northern segment was covered by the Mesozoic stratum in the east Tibet. From along Yingpan Couty in Lanping to Changning and Menglian, ophiolite tectonic massif formed by carboniferous flysch clastic rocks, carbonate rocks, containing radiolaria silicalite and serpentinization dunite, harzburgite and kylite, cumulate and mid-ocean ridge basalt was exposed (Hu et al., 1995; $\mathrm{Li}, 2012$; Wang et al., 2000) [8, 10, 15]. Laochang gold deposit, has been discovered in the belt. Like other suture zone, this metallogenic belt is also a place where shear zone type gold deposits have concentrated distribution. It has a prospect to discover large and medium-sized gold deposits.

\subsection{Zuogong-Baoshan Mineralization Belt}

The metallogenic belt is located in the Zuogong-Baoshan microplate, between the Lanchang River suture zone and the Nujiang suture zone. It can be further classified into two metallogenic subzones.

The north section is Leiwuqi-Gengma metallogenic subzone, distributed in the area from Leiwuqi to Gengma. The basement is the Pre-Devonian Jiayuqiao
Group metamorphic rocks, above which are Carboniferous System, the Triassic and the Jurassic volcanic rocks and the Paleogene-Neogene continental facies coal-bearing clastic rocks. The Yanshan early granite intrusive activity has developed and many lead and zinc deposits have been found on the edge of the granite and in the contact zone of surrounding rocks, which is of good prospecting prospect.

The south section is Baoshan metallogenic subzone, located in the Baoshan plot. The emergence stratum is the Sinian System to the Neogene System and the main lithological association is the Sinian System flysch sand slate. The Ordovician to Permian are neritic facies clastic rocks, including glacial boulder clastic rock, Carbonate rock and basalt; the Mesozoic Erathem is clastic rocks with intermediate-basic volcanic rocks. The stratigraphic distribution of the Neogene System is distributed scatteredly and the system is continental facies coal-bearing clastic rocks. Caledonian granite intrusive activity has developed. And the Armao tungsten deposit has been found now. The Caledonian Period, Hercynian, the Early Yanshan, the Late Yanshan and Himalayan granite intrusive activity have developed and with Sn, W, Pb, Zn, Au mineralization. At present, AmoTin and Tungsten deposit, Changtong lead and zinc deposit, Mengxin lead and zinc deposit, ZhenanTin deposit, Pingdatin deposit, Pingda, Xiyi lead and zinc deposit, Luziyuan, Hetaopin $\mathrm{Cu}, \mathrm{Pb}$ and $\mathrm{Zn}$ skarn type deposit and several metal ore occurrences have been discovered in this area (Hu et al., 1995; Li et al., 2011; Li and Zeng, 2012; Wang et al., 2000) [8-10, 15]. This is a good prospecting prospect.

\subsection{Nujiang Mineralization Belt}

The tectonic melange belt is of abyssal flysch clastic rocks developed in the late Triassic Epoch to Middle Jurassic as the matrix. Various tectonic rocks including mid-oceanic ridges basalt, sedimentary rocks and flysch are distributed along the fault zone, which is the ophiolitic melange belt formed due to 
strong plate collision as the result of the close of the Late Yanshan Nujiang Ocean Basin. There is Yanshanian acidic magmas intrusion along the fault zone. Dingqing chromite deposit and other deposits have been found in the ultramafic rock. Multi-period tectonic magmatic activities had provided very favorable minerogenetic conditions for the activation, migration and enrichment of mineralization of gold scattered in this area. So the fault zone is also concentratedly distributed with shear zone gold deposit with good prospecting prospect.

\subsection{Bomi-Tengchong Mineralization Zone}

The metallogenic belt is located in the Bomi-Tengchong microplate for the Gangdise and Tengchong metallogenic belt of the middle and southern. The main developed stratums in the middle and south section of the Gangdise-Tengchong Metallogenic Belt are Precambrian System Guqin Group, Gaoligong mountains Group of schist, gneiss marble and migmatite, etc., and the emergence is Ordovician to Permian clastic rocks and carbonate rocks, basic volcanic rocks and contain in glacial boulder clastic rock. The scattered emergence is Upper Triassic series and Cenozoic Erathem clastic rocks and volcanic rock. The Early Yanshan, the Late Yanshan and Himalayan granite intrusive activity have developed and with $\mathrm{Sn}, \mathrm{W}, \mathrm{Cu}, \mathrm{Pb}, \mathrm{Zn}, \mathrm{Ag}, \mathrm{Au}$, $\mathrm{Nb}$ and Ta mineralization and Xinqi granite Sn, W, $\mathrm{Nb}$ and Ta deposits in Xiaolong River have been found. Also, Tiegao mountain and Datongchang Sn, $\mathrm{W}, \mathrm{Nb}$ and Ta skarn type deposits, Laili mountain tin deposit and Liuhongchang vein type skarn type lead and zinc silver gold deposit and several metal ore occurrences have been discovered in this area (Hu et al., 1995; Li et al., 2011; Li and Zeng, 2012; Liu et al., 1993; Wang et al., 2000; Ma, 1990; Mao et al., 1987; Mo et al., 2001) [8-10, 13, 15, 25, 28, 29].

\section{Tectonic Evolution and Metallogeny}

The metallogenesis and metallogenic regularities of metallic mineral deposit in the Nujiang-Lancang-Jinsha Rivers (southwest Sanjiang) area in the southwest are closely related to the tectonic evolution in this region. This region has experienced Paleo-Tethys, Meso-Tethys and Neo-Tethys geological development phases. According to the characteristics of stratums, tectonization and magmation in this region, the tectonic evolution and metallogenesis in three-river area can be divided into the following evolutionary phases (Fig. 3).

\subsection{Cambrian to Devonian Epoch}

The region belongs to the ancient Yangtze Plate and the neritic facies stable-transitional clastic rocks and carbonate rocks have developed as the sedimentary formation to form the original source bed of metals such as copper, lead, zinc, silver and gold, preparing metallogenic materials for the future tectonic activation and metallogenesis.

\subsection{Carboniferous to Early Permian Epoch}

In the Carboniferous Period, when the Langcangjiang Ocean and the Jinshajiang Ocean successively entered the expansion period, the evolutionary phase of the Paleo-Tethys Ocean started and the interior was neritic facies carbonate rocks. To Early Permian Epoch, the Langcangjiang Ocean Crust subducted under the Changdu Microplate to form the Jiangda-Weixi-Lvchun continental marginal arc volcanic rock belt and the expansion of the Jinshajiang Ocean reached its peak. The Changdu area in west Tibet was still neritic-littoral facies sediment and the continental marginal arc volcanic rocks were formed. Another original source bed of metals such as copper, lead, zinc, silver and gold was formed.

\subsection{Late Permian Epoch to Middle Triassic Epoch}

In the Late Permian Epoch, the Langcangjiang Ocean Crust was approximately closed and the Jinshajiang Ocean began to subduct under the Cangdu Microplate, to form the Jiangda West China Period 


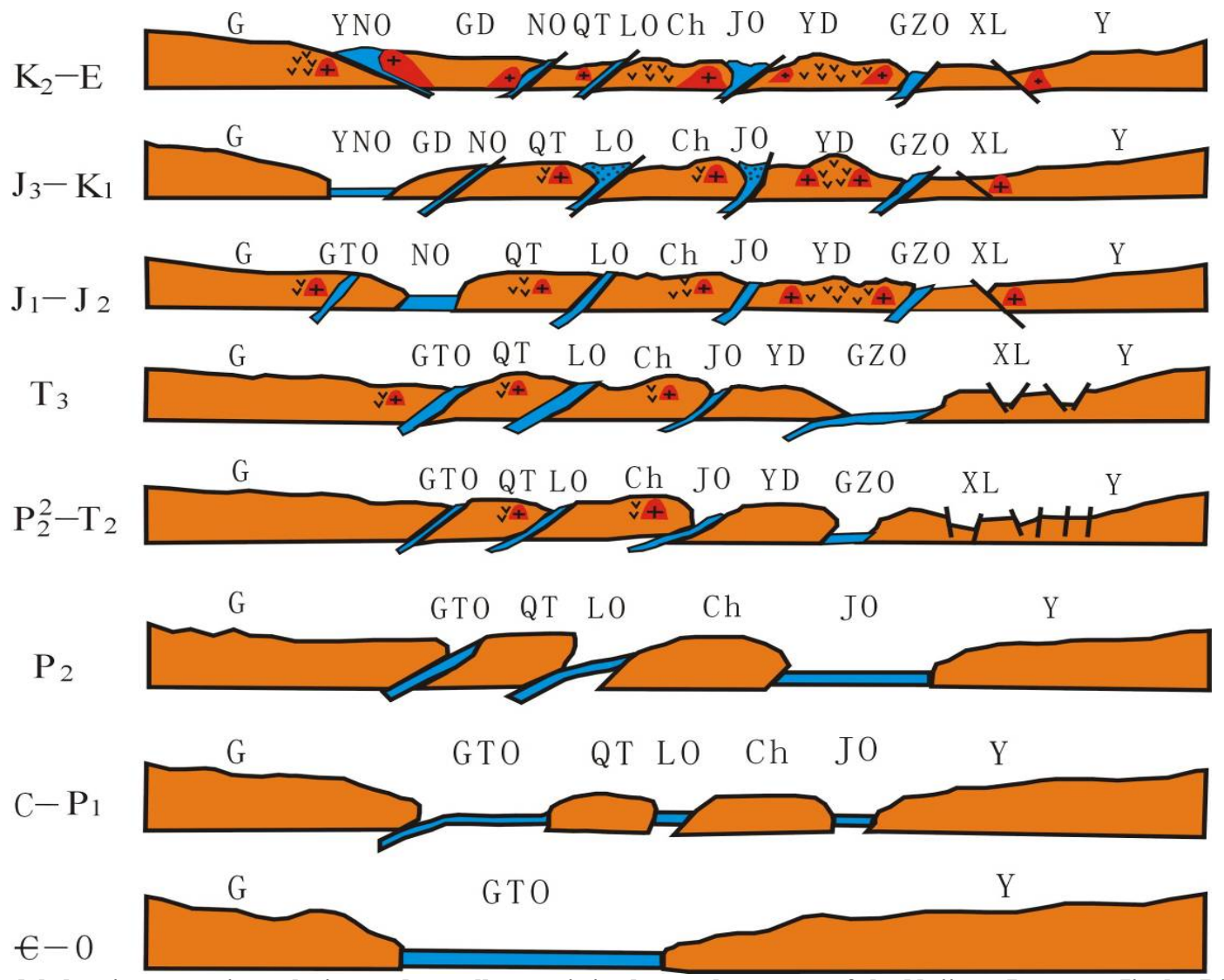

Fig. 3 Model showing tectonic evolution and metallogenesis in the southern part of the Nujiang-Lancang-Jinsha Rivers.

G—Gondwanaland; GD—Gangdise Plate; QT—QiangTang Plate; Ch—Qamdo Plate; YD-Yidun Island; Y—Yangtze Plate; Z-Zhongza Plate; GTO_Propaleo Tethys Ocean; LQ_Lancangjiang Ocean and junction; LO_Jinshajiang Ocean and junction; GLO-Garze-Litang Ocean and junction; NO-Nujiang Ocean and junction; YNO-Yarlung Zangbo River and junction; XL-Xianshui River fault zone.

granite arc, Zaduo-Jinghong Island Arc Belt and Zhubalong-Gongka volcanic valve. With the collision of Eurasia and Gondwana Plate, the development phase of Tethys ended and the revolutionary phase of Meso-Tethys began. As the compensation for westward subduction of the Jinshajiang Ocean Crust, the southwest edge of the Yangtze Plate was of wide ground fracturing to form the Ganzi-Litang-Xianshui River initial fault zone and the geosyncline flysch formation with a thickness of more than 10,000 m was deposited, preparing a source bed for the stratabound metallization. At the initial revolutionary stage of the sedimentary basin, it was a back-arc basin with multiple fracture centers. In these fault belts, only Ganzi-Litang had further developed into Ganzi-Litang Ocean Basin.

\subsection{Late Triassic Epoch: Since Late Triassic Epoch}

With the westward subduction of the Ganzi-Litang Ocean Crust, Yidun Island was formed gradually and the arc volcano-flysch sedimentary formation was developed with strong eruptive activity of the volcano and with $\mathrm{Cu}, \mathrm{Pb}, \mathrm{Zn}, \mathrm{Au}, \mathrm{Ag}$ and $\mathrm{Hg}$ mineralization. The super-large volcanogenic massive sulfide deposit was formed in Dege-Xiangcheng volcanic deposit basin, for example, Gacun in the region was of super-large polymetallic deposits rich in gold and silver. At the end of Triassic Epoch, Ganzi-Litang Ocean was closed and the western Sichuan lifted as land and the late revolutionary phase of Meso-Tethys started. Due to the Indosinian movement, the Yidun area in western Sichuan was of Indosinian granite 
magma intrusion along the fracture and fold shaft to form Queershan-Daocheng Granite Belt; Indosinian Qiao Hypabyssal-Superhypabyssal Intermediate-acid rock zone was formed in Pulang in Yunnan Province within the Yidun Island arc and Pulang super-large porphyry copper deposit was also formed; Dapingzhang volcanic copper ore deposit was formed due to the collision of Zaduo-Deqin-Jinghong-Didao arc volcanic rocks and collision arc volcanic. In the island arc volcanic and collision arc volcanic, Dapingzhang, Sandashan, Minluo, Guanfang and Wenyu volcanic type copper deposit have been discovered.

\subsection{Jurassic to Cretaceous}

With the close of Ganzi-Litang Ocean Basin, the Nujiang Ocean was formed in Early and Middle Jurassic. In Late Jurassic, the Nujiang Ocean was closed due to the subduction and collision of the oceanic crust. The Yarlungzangbo Ocean was formed in Early Cretaceous Epoch and closed in Late Cretaceous Epoch-Eocene Epoch. Due to the collision of the Indian Plate and Lhasa Plate, the evolutionary phase of Meso-Tethys ended. The continued collision between plates in Jurassic and Cretaceous Period in eastern Tibet led to the tectonic activity of the Jinshajiang Suture Zone, Ganzi-Litang Suture Zone and Lancangjiang Suture Zone, thus causing magmation and metallogenesis. For example, the Yanshanian magmation in the Yidun area in western Sichuan was multi-period, forming the Yidun-Genie Granite Belt and with Sn, W, Cu, Pb, Zn, Ag and Au mineralization. The early Yanshan and granite intrusive activity has developed and gold, copper and lead and zinc deposits.

\section{Prospecting Direction}

In the southwest, Sanjiang area four-plate suture zones, ductile shear zone development, related to ductile shear structure zone of gold mine to mine development, is to find the main area of the ductile shear zone gold deposits. Strengthen the research and the ductile shear zone gold ore exploration work, is expected to find a new gold deposits. In addition, the four-plate suture zone of magnesium and iron in the rock on prospecting work is expected to find Ding Qing type chromite deposit.

In volcanic sedimentary basin in this area, to strengthen the volcanic mechanism research, volcanic deposits and mineralization characteristics, combining with the geophysical and geochemical exploration and remote sensing geology and results of comprehensive research, carried out prospecting rake area detailed large scale regional geological mapping and alteration ore into the study of the ore belt and the ore prospecting and metallogenic prediction research work, is expected to discover new ore bodies, find new marine volcanic type gold deposits.

Strengthen the regional various granite and mineralization, granite porphyry belt features and geophysical, geochemical and remote sensing geological results of comprehensive study, carried out the detailed prospecting rake area of large scale regional geological mapping and anatomic studies of the geophysical and geochemical anomalies in ore prospecting and metallogenic prediction research work, is expected to discover new ore bodies, find new porphyry, skarn type, medium to low temperature liquid type polymetallic deposit.

To strengthen the turbidity current deposits in basin of turbidite mineralization characteristics and mineralization of the study, combined with the comprehensive research of geophysical, geochemical and remote sensing geological achievements, carry out the detailed prospecting target areas of large scale regional geological mapping and anatomic studies of the geophysical and geochemical anomalies are expected to find new turbidite rock type gold deposit.

Strengthen the dome structure in karst caves in carbonate formation and tectonic fracture zone of gold mineralization and geophysical, geochemical and 
remote sensing geological results of comprehensive research, carry out ore prospecting and metallogenic prediction research work, is expected to find EarZe karst type stratabound gold deposit.

Deep geological effect of southwest Sanjiang area for deposit and its mineralization and ore prospecting and metallogenic prediction research work, is expected to find new orebody and ore deposit.

\section{Conclusions}

The Nujiang-Lancang-Jinsha Rivers (southwest Sanjiang) area has experienced the geological evolutionary phase of the Paleo-Tethys, Meso-Tethys and Neo-Tethys. The multiple tectonic-magmatic activities have occurred, creating favourable conditions for metallic ore deposits formation, where is one of the most important ore concentration areas in China. The metallogenesis and metallogenic regularities of metallic mineral deposit in the region areas in the southwest are closely related to the tectonic evolution in this region.

Geotectonic position is the Nujiang-Lancang-Jinsha Rivers can be divided into nine tectonic units and nine mineralization zones.

The plates of southwest Sanjiang area have experienced four evolution stages that include the seafloor spreading, subduction of oceanic crust, land-arc collision and intracontinental convergence stage. As a result of different evolutionary stages of mineralization, it appears different mineral characteristics. In plate junction, where mainly includes mafic-ultramafic magmatic-type copper-nickel, chromium, gold and other minerals. Strata-bound iron, lead, zinc, copper, gold deposits, around Junggar mainly include porphyry, mafic-ultramafic magmatic, volcanic rock-type copper-molybdenum, nickel, chromium, gold and other minerals. In plate, where mainly includes porphyry, magmatic-type, volcanic rock-type copper-molybdenum, nickel, chromium, gold, iron, lead, zinc deposits, and other minerals.
Strengthen the regional geological effect and mineralization, metallogenic belt features and geophysical, geochemical and remote sensing geological results of comprehensive study, carried out the detailed prospecting rake area of large scale regional geological mapping and anatomic studies of the geophysical and geochemical anomalies in ore prospecting and metallogenic prediction research work, is expected to discover new ore bodies, find new deposit.

\section{Acknowledgements}

This work was supported by China Geological Survey (Grant No. H45C004002, 1212010784007, ZKD-94-17) and the Project of the National Natural Science Foundation of China (Grant No. 40272012).

\section{References}

[1] BGMRS (Bureau of Geology and Resources of Sichuan). 1991. Regional Geology of Sichuan. Beijing: Geological Publishing House. ( in Chinese)

[2] BGMRX (Bureau of Geology and Mineral Resources of Xizang Autonomous Region). 1993. Regional Geology of Xizang (Tibet). Autonomous Region. Beijing: Geological Publishing House. (in Chinese)

[3] BGMRY (Bureau of Geology and Resources of Yunnan). 1990. Regional Geology of Yunnan. Beijing: Geological Publishing House. (in Chinese)

[4] Chen, B. W., Wang, K. Y., Cai, Z. J., Zhang, Q. W., Peng, X. J., Qiu, Y. Z., and Zheng, Y. Z. 1987. The NujiangLancangjiang-Jinshajiang Region. Beijing: Geological Publishing House. (in Chinese)

[5] Hou, Z. Q., and Mo, X. X. 1991. "Formation and Evolution of Yidun Volcanic Island Arc and Its Cont Rolling Effects on Kuroko Type of Massive Sulfide Deposits in Sanjiang Region.” Earth Science-Journal of China University of Geosciences 16 (2): 153-64 (in Chinese).

[6] Hou, Z. Q., Mo, X. X., and Yang, Z. M., 2006. "Metallogeneses in the Collisional Orogen of the Qinghai-Tibet Plateau: Tectonic Setting, Tempospatial Distribution and Ore Deposit Types." Geology in China 33 (2): 340-51. (in Chinese)

[7] Huang, J. Q., and Chen, B. W. 1987. The Evolution of Tethys in China and Adjacent Regions. Beijing: Geological Publishing House. (in Chinese)

[8] Hu, Y. Z., Wang, H. P., and Tang, S. H. 1995. Gold Mine 
Geology in Ailaoshan. Beijing: Geological Publishing House. (in Chinese)

[9] Li, W. C., Liu, X. L., and Zeng, P. S. 2011. “The Characteristics of Metallogenic Rocks in Pulang Porphyry Copper Deposit of Yunnan Province.” Geology in China 38 (2): 403-14. (in Chinese)

[10] Li, W. C., and Zeng, P. S. 2012. "Characteristics and Metallogenic Model of the Pulang Superlarge Porphyry Copper Deposit in Yunnan, China.” Journal of Chengdu University of Technology (Science \& Technology Edition) 34 (4): 436-46. (in Chinese)

[11] Li, X. Z., Jiang, X. S., Sun, Z. M., Shen, G. F., and Du, D. $\mathrm{X}$. 2002. Collide Orogenetic Process of the Nujiang-Lancangjiang-Jinshajiang Area, Southwest China. Beijing: Science Press. (in Chinese)

[12] Liu, Z. Q., Xu, X., Pan, G. T., Li, T. Z., Yu, G. M., and Yu, X. J. 1990. Tectonics and Evolution of the Tibetan Plateau. Bejing: Geological Publishing House. (in Chinese)

[13] Liu, Z. Q., Li, X. Z., Ye, Q. T., Luo, J. L., and Shen, G. F. 1993. Division of Tectono-Magmatic Zone and the Distribution of Deposits in the Sanjiang Area (Nujiang-Lancang-Jinsha Rivers Area). Bejing: Geological Publishing House. (in Chinese)

[14] Pan, G. T. 1994. "An Evolution of Tethys in Global Ocean-Continent Transformation.” Tethyan Geology 18: 23-39. (in Chinese)

[15] Wang, Y. Z., Li, X. L., Duan, L. L., and Cui, C. L. 2000. Geotectonics and Metallogeny in the South Nujiang-Lancang-Jinsha Rivers Area. Beijing: Geological Publishing House. (in Chinese)

[16] Xiao, X. C., Li, T. D., Li, G. C., Gao, Y. L., and Xu, Z. Q. 1990. "Tectonic Evolution of the Qinghai-Xtzang (Tibet) Plateau.” Acta Geoscientia Sinica 11 (1): 123-5. (in Chinese)

[17] Xu, Z. Q., Hou, L. W., and Wang, Z. X. 1992. Orogenic Processes of the Songpan-Garze Orogenic Belt of China. Beijing: Geological Publishing House. (in Chinese)

[18] Yin, A. 2000. "Geologic Evolution of the Himalayan-Tibetan Orogen in the Context of Phanerozoic Continental Growth of Asia.” ACTA Geoscientia Sinica 22 (3): 193-230. (in Chinese)

[19] Zhong, D. L. 1998. Paleotethysides in West Yunnan and Sichuan, China. Beijing: Science Press. (in Chinese)
[20] Zou, G. F. 1996. "Relationship between Type Gold Deposits and the Geological Evolution of the Tethys in West Sichuan and Eastern Xizang.” Acta Geological Sichuan 16 (1): 46-53. (in Chinese)

[21] Pan, G. T., Xu, Q., Hou, Z. Q., Wang, L. Q., Du, D. X., Mo, X. X., Li, D. M., Wang, M. J., Li, X. Z., Jiang, X. S., and $\mathrm{Hu}, \mathrm{Y} . \mathrm{Z}$. 2003. Archipelagic Orogenesis, Metallogenic Systems and Assessment of the Mineral Resources along the Nujiang-Lancang-Jinsha Rivers Area in Southwestern China. Beijing: Geological Publishing House. (in Chinese)

[22] Li, W. C., Yu, H. J., and Yin, G. H. 2013. "Porphyry Metallogenic System of Geza Arc in the Sanjiang Region, Southwestern China.” Acta Petrologica Sinica 29 (4): 1129-44. (in Chinese)

[23] Zou, G. F., and Mao, J. Y. 1996. "Relationship between Tectonic Evolution and Gold Deposit in Ganzi-Litang Fracture Zone." Journal of Chengdu University of Technology 25 (2): 233-40. (in Chinese)

[24] Lu, B. X., Wang, Z., and Zhang, N. D. 1993. Granitoids in the Sanjiang Region and their Metallogenic Specialization. Beijing: Geological Publishing House. (in Chinese)

[25] Mao, J. W., Zhang, S. L., Rossi, P. 1987. "The Tin-Oranites and Their Relation to Mineralization in Tengchong, Yunnan.” Acta Petrologica Sinica 11 (4): 32-43. (in Chinese)

[26] Tang, R. L., and Luo, H. S. 1995. Porphyry Copper (Molybdenum) Geological Ore Belt in Yulong, Tibet. Beijing: Geological Publishing House. (in Chinese)

[27] Luo, J. L., Du, D. X., Hui, L., and Zhu, K. Y. 1999. Sedimentary Geology and Metallogenesis in the Nujiang-Langc-Lancang-Jinsha Rivers Area, Southwestern China. Bejing: Geological Publishing House. (in Chinese)

[28] Ma, H. W. 1990. Petrology of Granites and Related Mineralization in Yulong Porphyry Copper Belt, Tibet. Wuhan: China University of Geosciences. (in Chinese)

[29] Mo, X. X., Deng, J. F., Dong, F. L., Yu, X. H., Wang, Y., Zhou, S., and Yang, W. G. 2001. "Volcanic Petrotectonic Assemblages in Sanjiang Orogenic Belt, SW China and Implication for Tectonics.” Geological Journal of China Universities 7 (2): 121-38. (in Chinese) 